\title{
Aging Mechanisms of Electrode Materials in Lithium-Ion Batteries for Electric Vehicles
}

\author{
Cheng Lin, ${ }^{1,2}$ Aihua Tang, ${ }^{1,2,3}$ Hao Mu, ${ }^{1,2}$ Wenwei Wang, ${ }^{1,2}$ and Chun Wang ${ }^{1,2,3}$ \\ ${ }^{1}$ National Engineering Laboratory for Electric Vehicles, School of Mechanical Engineering, Beijing Institute of Technology, \\ Beijing 100081, China \\ ${ }^{2}$ Collaborative Innovation Center of Electric Vehicles in Beijing, Beijing Institute of Technology, Beijing 100081, China \\ ${ }^{3}$ School of Mechanical Engineering, Sichuan University of Science \& Engineering, Zigong 643000, China
}

Correspondence should be addressed to Aihua Tang; tahme@163.com

Received 16 March 2015; Revised 24 May 2015; Accepted 26 May 2015

Academic Editor: Noshin Omar

Copyright (C) 2015 Cheng Lin et al. This is an open access article distributed under the Creative Commons Attribution License, which permits unrestricted use, distribution, and reproduction in any medium, provided the original work is properly cited.

\begin{abstract}
Electrode material aging leads to a decrease in capacity and/or a rise in resistance of the whole cell and thus can dramatically affect the performance of lithium-ion batteries. Furthermore, the aging phenomena are extremely complicated to describe due to the coupling of various factors. In this review, we give an interpretation of capacity/power fading of electrode-oriented aging mechanisms under cycling and various storage conditions for metallic oxide-based cathodes and carbon-based anodes. For the cathode of lithium-ion batteries, the mechanical stress and strain resulting from the lithium ions insertion and extraction predominantly lead to structural disordering. Another important aging mechanism is the metal dissolution from the cathode and the subsequent deposition on the anode. For the anode, the main aging mechanisms are the loss of recyclable lithium ions caused by the formation and increasing growth of a solid electrolyte interphase (SEI) and the mechanical fatigue caused by the diffusioninduced stress on the carbon anode particles. Additionally, electrode aging largely depends on the electrochemical behaviour under cycling and storage conditions and results from both structural/morphological changes and side reactions aggravated by decomposition products and protic impurities in the electrolyte.
\end{abstract}

\section{Introduction}

Lithium-ion cells are attractive candidates for power storage owing to their high power and energy-density and low selfdischarge rate. At present, they are widely used in portable instruments, communication equipment, and so forth. During the past few years, lithium-ion cells have been extensively applied in automobiles such as hybrid electrical vehicles (HEVs), plug-in hybrid electric vehicles (PHEV), and blade electric vehicles (BEVs) [1]. The goals of the Freedom CAR research, initiated by the United States Advanced Battery Council (USABC), require a 15-year lifespan of battery systems for HEVs and a 10-year lifespan for BEVs. As such, a lifetime of lithium-ion cells of up to 1000 cycles at an $80 \%$ depth-of-discharge (DOD) is required according to the cycling life [2].

Unfortunately, the life span of a lithium-ion cell, as is generally known, is restricted by side reactions that may be detrimental to the cell's component parts, which include the active lithium, binder, current collectors, the separator, conducting salt and solvents, and these reactions result in a capacity decrease/resistance rise of the cell [3-5]. In particular, the electrolyte's components are sensitive to exposure to different temperatures and operating conditions [6].

Understanding the electrode aging mechanisms in lithium-ion batteries is of great importance to address the life time and safety challenges, to make precise lifetime predictions, and to improve the battery performance [7]. For lithium-ion batteries, the impacts of the multiple factors contributing to electrode aging are not independent but instead have synergistic effects on battery aging [4]. Thus the explanations for capacity/power fading and the resistance rise are not given in terms of a single factor, which complicates the understanding of electrode material aging, and many researchers have been making great efforts to explore the aging mechanisms for many years [8]. 


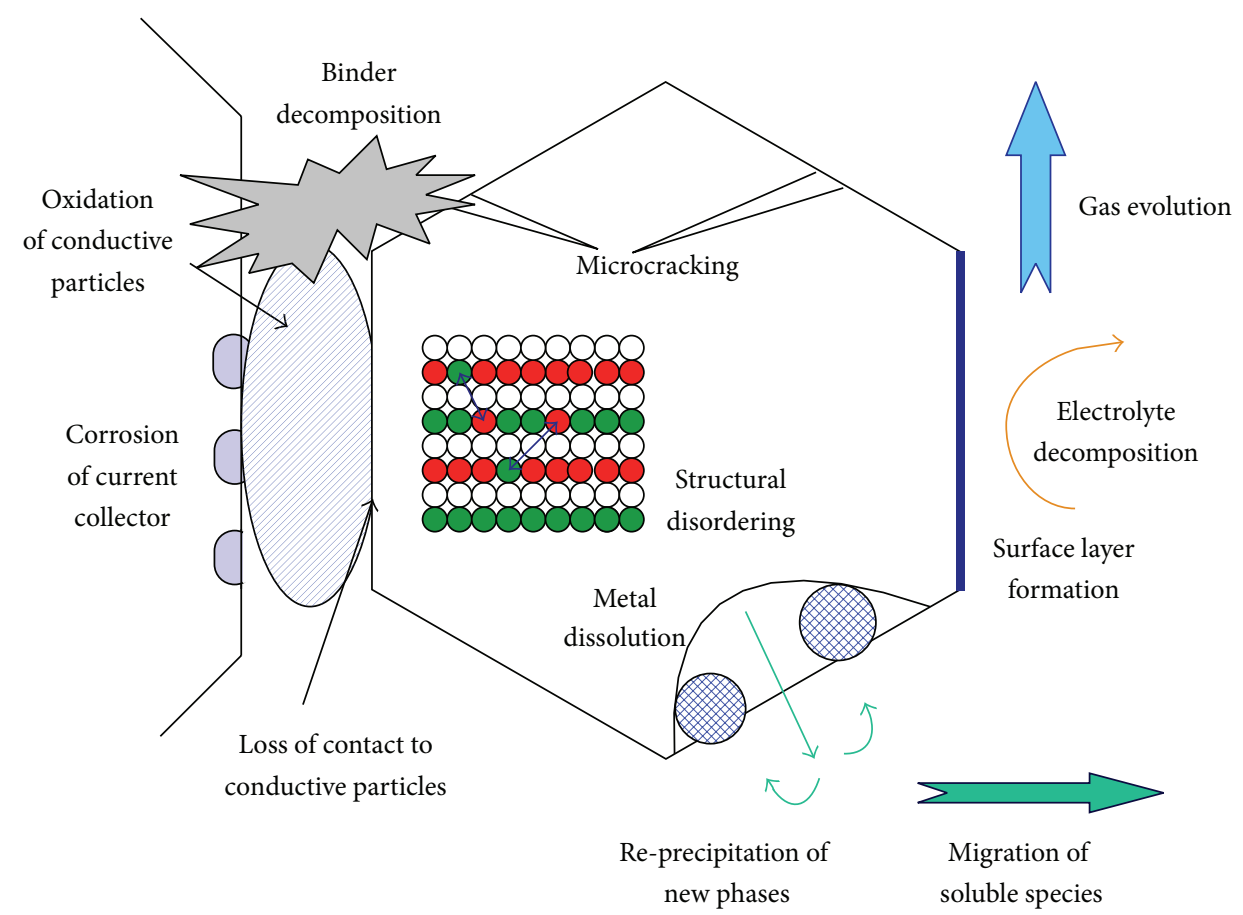

FIGURE 1: Schematic diagram of the aging mechanisms of cathode materials.

This paper attempts to study and summarize the present research regarding the predominant aging mechanisms of the positive electrode (metallic oxide cathode) and the negative electrode (carbon anode) of lithium-ion cells applied to EVs. Because the aging mechanisms of the cathode and anode are obviously different, they are discussed in separate sections. First, the aging mechanisms of the positive electrode materials are presented, with explanations of the aging phenomenon originating from the dominant factors. Later, we elaborate on the SEI evolution and some basic aging mechanisms affecting the negative electrode. Finally, the influences of the electrolyte on the cathode and anode, ageing itself, the thermal stability, and the hydrolysis reaction at ambient temperatures are discussed in the corresponding sections.

\section{Aging Mechanisms of the Positive Electrode}

Cathode materials determine significantly not only the performance of lithium-ion batteries but also their calendar and cycle lives. Lithium-manganese-oxides $\left(\mathrm{LiMn}_{2} \mathrm{O}_{4}\right)$ with spinel structures and lithium-nickel-cobalt-mixed-oxides $\left.(\mathrm{LiNiCoO})_{2}\right)$ with layered structures are widely accepted as the choices of cathode materials for applications in high-energy and power-dense batteries according to the factors of cost, abundance, and performance, and they have been extensively studied in recent years $[9,10]$.

Figure 1 from [11] is a schematic diagram showing the main aging mechanisms for cathode materials. In the beginning, aging occurs in the battery's electrolyte, and the origin can be electrochemical, mechanical, or thermal and is strongly dependent on the electrode materials [2, 9]. Aging causes degradation of cell parts over the whole life cycle
[10], which leads to changes of the structural characteristics, decomposition of the blinder/electrolytes, formation of a surface layer and metal dissolution, and so forth [3]. Some basic aging mechanisms under cycling and different storage conditions for each type of cathode materials $\left(\mathrm{LiMn}_{2} \mathrm{O}_{4}\right.$ and $\mathrm{LiNiCoO}_{2}$ ) will be discussed separately because of their obvious distinction; moreover, the capacity fading and their preventive measures are also studied in this section.

2.1. Structural Factors. The insertion and extraction of lithium ions cause variation of the molar volume of the cathode materials. It also leads to mechanical stress and strain of the metallic oxide particles. Then, the emergence of phase transitions can subsequently cause crystal distortion and further mechanical stress (Figure 1). The reversible electrochemical reactions of the cathode materials are in progress as the lithium ions are inserted/extracted in/from the lithiummanganese-oxides and are expressed by

$$
\mathrm{LiMn}_{2} \mathrm{O}_{4} \rightleftarrows \mathrm{Li}_{x} \mathrm{Mn}_{2} \mathrm{O}_{4}+(1-x) \mathrm{Li}^{+}+(1-x) \mathrm{e}^{-}
$$

The $\mathrm{LiMn}_{2} \mathrm{O}_{4}$ spinel has a cubic structure with $\mathrm{Mn}$ located on octahedral 16d sites and Li ions on 8a tetrahedral sites in a cubic close-packed array of oxygen anions. At low potentials below $3 \mathrm{~V}$ versus $\mathrm{Li} / \mathrm{Li}^{+}, \mathrm{Li}$ ions are inserted into vacant octahedral sites and produce a JahnTeller distorted tetragonal phase: $\mathrm{Li}_{2} \mathrm{Mn}_{2} \mathrm{O}_{4}$. Furthermore, a significant phase conversion appears which causes fracturing, decrepitation of the electrode, and loss of contact to conductive particles, thus resulting in rapid capacity fading during the charging and discharging operations [11, 12].

In the most recent literature [13-19], further phase transitions taking place within $\mathrm{LiMn}_{2} \mathrm{O}_{4}$ spinel have been 
confirmed. The shapes of the superstructure phase of the lithium at $x=0.5$ [20] and the double hexagonal phase [21] must be maintained for the purpose of achieving good cycling stability. Some measures, such as the partial replacement of manganese ions by excess lithium and/or by divalent or trivalent cations such as $\mathrm{Al}, \mathrm{Mg}, \mathrm{Co}$, and $\mathrm{Cr}$ [22-32], can be adopted to diminish the molar volume changes of particles during the cycle to improve the capacity retention.

In the lithium-nickel-cobalt-oxide system, the $\mathrm{LiNiO}_{2}$ and $\mathrm{LiCoO}_{2}$ compounds have the $\alpha-\mathrm{NaFeO}_{2}$ crystallized layer structure, consisting of a cubic close-packed oxygen array with transition metal and lithium ions occupying octahedral sites in alternating layers [12]. It is difficult to synthesise a pure $\mathrm{LiNiO}_{2}$ compound because of the structural disorder reaction, which is given by

$$
\begin{aligned}
\mathrm{LiNiO}_{2} \rightleftarrows & \left\{\mathrm{Li}_{1-x} \mathrm{Ni}(\mathrm{II})_{x / 2}\right\} \mathrm{Ni}(\mathrm{III})_{1-x} \mathrm{O}_{2-x}+\frac{x}{2} \mathrm{Li}_{2} \mathrm{O} \\
& +\frac{x}{4} \mathrm{O}_{2}
\end{aligned}
$$

However, lithium-nickel-disorder will decrease as the cobalt content increases. Meanwhile, monoclinic/hexagonal phase transitions arise in pure lithium-nickel-oxide, during the process of electrochemical lithiation/delithiation, and can be prevented by a cobalt content of approximately 20 mole $\%$ $[12,22]$.

Additionally, there are two kinds of new electrode materials: $\mathrm{LiNi}_{0.8} \mathrm{Co}_{0.15} \mathrm{Al}_{0.05} \mathrm{O}_{2}$ (NCA) $[33,34]$ and $\mathrm{LiNi}_{1 / 3} \mathrm{Mn}_{1 / 3} \mathrm{Co}_{1 / 3} \mathrm{O}_{2}$ (NMC) [35]. Compared with $\mathrm{LiNiO}_{2}$ and $\mathrm{LiCoO}_{2}$, they have higher specific capacities-despite their isostructure-and improved structural, chemical, and thermal stabilities [36]. The reduction in the amount of cobalt will improve the structure of the materials and reduce the cost compared to the parent compounds like $\mathrm{LiNiO}_{2}$ and $\mathrm{LiNi}_{1 / 2} \mathrm{Mn}_{1 / 2} \mathrm{O}_{2}$. The doping of $\mathrm{Al}$ in $\mathrm{LiNiO}_{2}$ will improve the thermal stability and low-level partial substitution of $\mathrm{Al}$ $[37,38]$ or Mn $[39,40]$ for cobalt in NMC also has been shown to improve the thermal behaviour [41] and cycling stability [42], whereas the addition of small amounts of Ti appears to increase the practical capacities and improves cycling over an extended voltage range $[12,22]$. Hence, incorporation of $\mathrm{Al}, \mathrm{Mg}$, or $\mathrm{Cl}$ in $\mathrm{LiNiCoO}_{2}$ leads to better cycle stability compared to undoped oxides [43-48]; moreover, the chargedischarge tests show that both the specific capacities and capacity retentions of $\mathrm{Cl}$-doped cathodes increase compared to those of the undoped materials, especially for the capacity retention in the high-voltage region [49-54].

\subsection{Surface Effects/Chemical Decomposition in Electrolytes.} The formation of surface membranes because of electrolyte oxidation and decomposition is mentioned in the literature [55-59]. At elevated temperatures, high-voltage storage induces side reactions such as some electrolyte decompositions at the cathode/electrolyte interface accompanied by $\mathrm{CO}_{2}$ gas evolution [60-62]. Then, the metallic oxide-coated cathode can contribute to oxidation reactions as an oxygen source itself by the formation of a subsurface membrane of oxide-phase defects of the rock-salt construction $[63,64]$.
The surface membrane on a lithium metallic oxide cathode is shown in Figure 1. The formation of a surface film on $\mathrm{LiMO}_{x}$-based $(\mathrm{M}=\mathrm{Co}, \mathrm{Ni}, \mathrm{Mn})$ cathodes as the source of an observed impedance increase upon cell cycling has been identified by Electrochemical Impedance Spectroscopy (EIS) techniques [65-71]. This means that $\mathrm{Li}^{+}$ions must also travel through an additional (solid electrolyte interphase- (SEI-) type) layer between the cathode and electrolyte, which will be further discussed in the next section. This rock-salt structure embodies the low conductivity character of lithium ions and causes the surface resistance rise of the electrode [11, 16, 7282].

2.3. Metal Dissolution. Metal dissolution, especially manganese dissolution occurring between lithium-manganeseoxides (spinel) and the electrolyte, is an important issue at elevated temperatures [16, 83-92]. The manganese dissolution causes a loss of active material and a subsequent capacity fading of the electrode. Apparently, manganese ions that are dissolved from the cathode move towards the anode, after which they merge into the SEI there, which will be further discussed in next section. This phenomenon can accelerate the electrolyte decomposition and aggravate the anode self-discharge. Accordingly, the existence of even a small amount of manganese in the electrolyte will affect the life span of the lithium-ion cell. Generally, two kinds of manganese dissolution are discussed, especially at elevated temperatures: dissolution occurring at low potentials and acid dissolution accelerated by hydrofluoric acid (HF) $[11,22]$. Moreover, the precipitation of various lithium-manganeseoxides on the cathode and loss of electronic contact of the manganese compound, such as $\mathrm{MnF}_{2}$ and $\mathrm{MnCO}_{3}$, resulting in resistance rise of the electrode have been investigated by scanning electron microscopy (SEM) and energy dispersive $\mathrm{X}$-ray analysis (EDX) [16]. In contrast to lithium-manganeseoxides, metal dissolution of lithium-nickel-cobalt-mixedoxides in an electrolyte appears to be negligible. Only a tiny amount of dissolution occurs, and a small amount of cobalt can be found on the anode when lithium-nickel-cobaltmixed-oxides are charged beyond a stable potential window of $4.2 \mathrm{~V}$ versus $\mathrm{Li} / \mathrm{Li}^{+}[93,94]$.

2.4. Conclusion on Cathode Aging. Table 1 provides a summary of the principal characteristics of cathode aging and the discussed measures that reduce the effects. As for the cathode, aging phenomena may be primarily ascribed to changes of the cathode materials' structures, surface effects and electrochemical reactions at the electrode/electrolyte interface, and metal dissolution. Furthermore, electrode aging is catalyzed by elevated temperatures, high $\triangle \mathrm{SOC}$ (state of charge), and high charge and discharge rates, among others. We conclude that the predominant aging mechanisms of the metallic oxide cathode can be summarized as follows:

(i) The aging of electrode materials that results from structural disordering and phase transitions can be reduced by using new active materials or by adjusting their compositions and controlling the charge cutoff voltage. 
TABLE 1: Aging mechanisms of lithium-ion cathode materials-causes, effects, and results.

\begin{tabular}{lcccc}
\hline Cause & Effect & Result & Reduced by & Enhanced by \\
\hline $\mathrm{Li}^{+}$insertion/extraction & Structural disordering & Capacity/power fading & $\begin{array}{c}\text { New materials } \\
\text { Material combinations }\end{array}$ & Undoped materials \\
\hline Phase transitions & $\begin{array}{c}\text { Crystal distortion } \\
\text { Further mechanical stress }\end{array}$ & Capacity fading & $\begin{array}{c}\text { Control charge } \\
\text { cutoff voltage }\end{array}$ & Overcharge \\
\hline Metal dissolution & $\begin{array}{c}\text { Reprecipitation of new phases } \\
\text { Loss of active material } \\
\text { Surface layer formation }\end{array}$ & $\begin{array}{c}\text { Capacity fading } \\
\text { Impedance rise }\end{array}$ & Temperature control & Elevated temperature \\
\hline Electrolyte decomposition & $\begin{array}{c}\text { Gas evolution } \\
\text { Surface layer formation }\end{array}$ & Impedance rise & $\begin{array}{c}\text { Alternative } \\
\text { conductive salts }\end{array}$ & $\begin{array}{c}\text { Protic impurities } \\
\text { High storage potentials }\end{array}$ \\
\hline
\end{tabular}

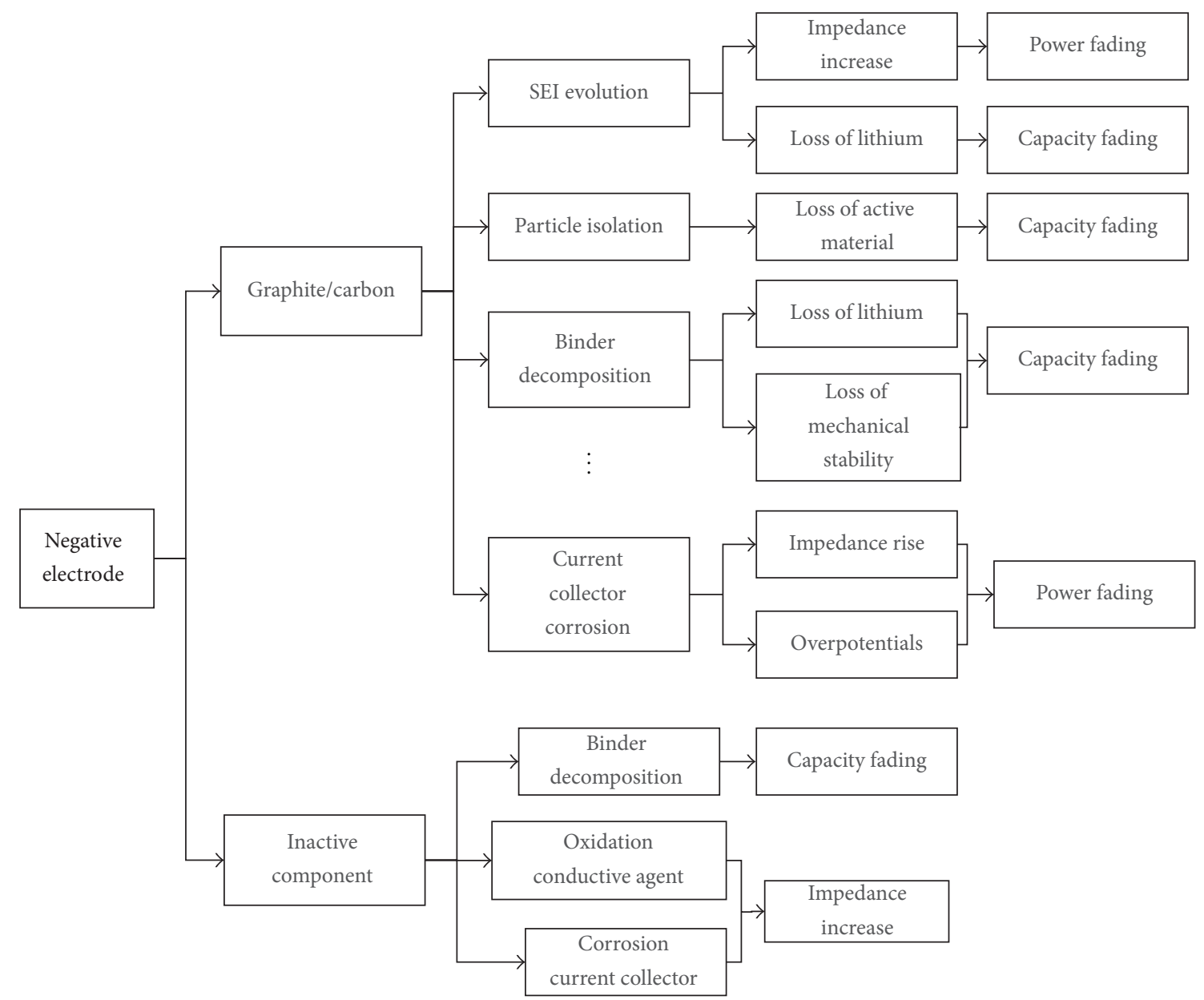

FIGURE 2: Aging mechanisms of the anode materials-causes, effects, and results.

(ii) Both electrochemical decomposition and formation of surface membranes can be reduced by operating within an appropriate temperature range and by controlling the charge cutoff voltage.

(iii) Metal dissolution, mainly in the form of Mn dissolution, can be restrained by avoiding deep discharge, blending the lithium-manganese spinel powder with lithium-nickel-cobalt-oxides, and using an alternative electrolyte.

\section{Aging of the Negative Electrode}

Generally, the most critical part of the cell is the anode/ electrolyte interface because of the high reactivity of the organic electrolyte with any type of electrode material and lithium ions. Graphite, carbon, amorphous silicon, and lithium titanium oxide are the main candidates for the anode materials [53, 71, 95-97]. Figure 2 from [11] shows a flowchart of the aging mechanisms for anode materials of a lithium-ion battery. To further the discussion, the anode aging under the 


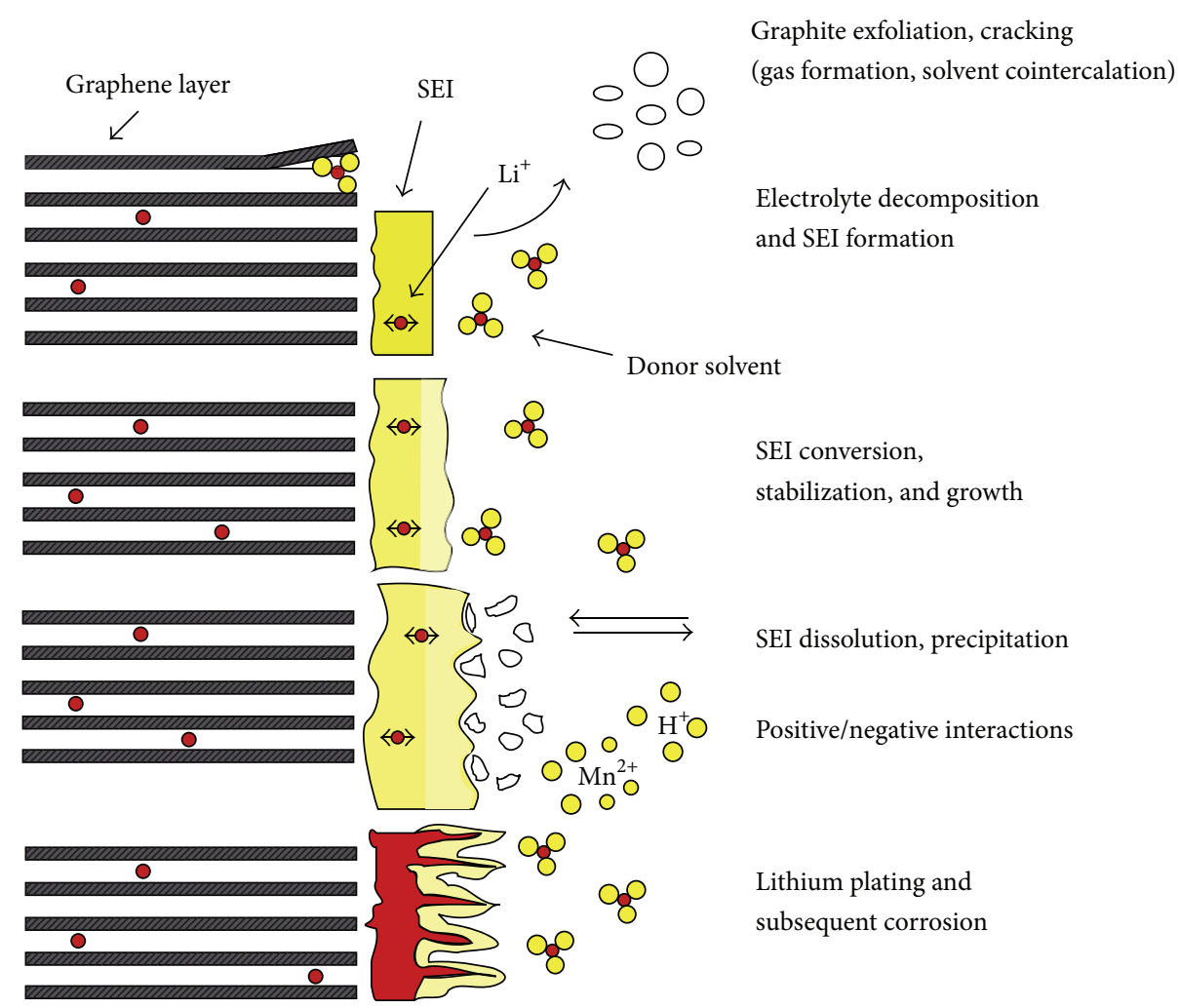

FIGURE 3: SEI evolution at the anode/electrolyte interface.

conditions of storage and use will be summarized in terms of the following: (i) SEI formation, stable growth, dissolution, and precipitation at the interface between the anodes and electrolytes; (ii) anode mechanical failure; and (iii) anode electrochemical aging.

\subsection{Evolution of the Passivated Surface Layer at the Anodel} Electrolyte Interface. Graphite is commonly adopted as the anode material for lithium-ion batteries with organic electrolytes, such as $\mathrm{LiPF}_{6}$, with cosolvents like ethylene carbonate (EC), dimethyl carbonate (DMC), diethyl carbonate (DEC), and methyl ethyl carbonate (EMC) [98]. Because the interface reactions take place between the composite anode and the electrolyte solution, changes at the anode and electrolyte interface are regarded by many researchers to be the main source of anode aging [7, 11, 16, 72-79]. When the anode operates at a potential that exceeds the electrochemically stable window of the electrolyte components, some major reactions in a $\mathrm{LiPF}_{6}$ salt system with $\mathrm{EC}$ and DMC are supposed to take place, and these reactions are listed below to show the processes and products $((3)-(8))$ [99-102].

As the reactions continue, the consumption of lithium ions and the electrolyte solvents are inevitable as the electrode is in a state of charge; then, the electrolyte decomposes and produces deposits. This process subsequently results in the formation of a protective, ionically conductive but electrically insulating passivation layer on the surface of the anode during the first charge cycle, the so-called SEI (e.g., $\mathrm{LiCO}_{3},\left(\mathrm{CH}_{2} \mathrm{OCO}_{2} \mathrm{Li}\right)_{2}, \mathrm{CH}_{3} \mathrm{OCO}_{2} \mathrm{Li}, \mathrm{Li}_{2} \mathrm{O}$, and $\left.\mathrm{LiF}\right)$, and the SEI evolution is illustrated in Figure 3, which is from [11]. Furthermore, the $\mathrm{ROCO}_{2} \mathrm{Li}$ can undergo a reduction reaction with traces of $\mathrm{H}_{2} \mathrm{O}$ and $\mathrm{CO}_{2}$ in the electrolyte to form $\mathrm{LiCO}_{3}$ [102-109], which further reacts with EC to form transesterification products [11,99-102]. Additionally, anion contaminates, such as $\mathrm{F}^{-}$from $\mathrm{LiPF}_{6}$, readily react with lithium ions to form insoluble reaction products $\mathrm{LiF}$, which are nonuniform, are electrically insulating, and are unstable on the surface of the graphite particles. When the side reactions continue during prolonged cycling, the produced deposits accumulate in the SEI and consequently lead to stable growth of the SEI, which, in turn, leads to the loss of active lithium and further decomposition of the electrolyte $[110,111]$. Subsequently, restructuring of the damaged SEI or a reprecipitation of the dissolved SEI products might occur as the SEI membrane begins to dissolve or to decompose $[16,102]$ :
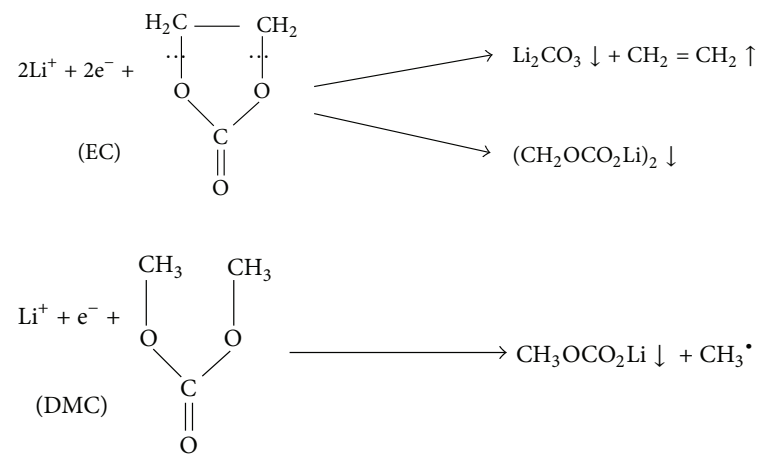


$$
\begin{gathered}
\mathrm{Li}^{+}+\mathrm{e}^{-}+\text {Trace } \mathrm{H}_{2} \mathrm{O} \longrightarrow \mathrm{LiOH} \downarrow+\frac{1}{2} \mathrm{H}_{2} \uparrow \\
\mathrm{LiOH}+\mathrm{e}^{-}+\mathrm{Li}^{+} \longrightarrow \mathrm{Li}_{2} \mathrm{O} \downarrow+\frac{1}{2} \mathrm{H}_{2} \uparrow \\
2 \mathrm{Li}^{+}+2 \mathrm{e}^{-}+2 \mathrm{CO}_{2} \longrightarrow \mathrm{LiCO}_{3} \downarrow+\mathrm{CO} \uparrow \\
n \mathrm{Li}^{+}+n \mathrm{e}^{-}+\mathrm{PF}_{6}^{-} \longrightarrow \mathrm{LiF} \downarrow+\mathrm{Li}_{x} \mathrm{POF}_{y} \downarrow
\end{gathered}
$$

In addition, interactions of the anode with the cathode must also be taken into account. For instance, metal is present on the anode surface. Dissolution of the cathode electrode metal from the lattice into the electrolyte can be caused by two main reaction mechanisms in the cell [11]. These reactions can be due to the disproportionation of $\mathrm{Mn}^{3+}$ to $\mathrm{Mn}^{2+}$ and $\mathrm{Mn}^{4+}$ ions at low states of charge or due to traces of $\mathrm{HF}$ within the $\mathrm{LiPF}_{6}$ electrolyte. Because manganese ions do not change their oxidation state to $\mathrm{Mn}^{3+}$ during storage within the NMC and the spinel phase, manganese dissolution caused by HF is more likely. Dissolved transition metals are transported through the electrolyte to the surface of the anode, resulting in the deposition of cation contaminates, such as $\mathrm{Mn}, \mathrm{Co}$, and $\mathrm{Fe}$, which are incorporated into the SEI layer [3, 4, 21, 98, 102].

Moreover, the graphite electrode materials are susceptible to lithium plating and lithium dendrite growth because of the close proximity of its reversible potential to that of $\mathrm{Li}^{+} / \mathrm{Li}$. Both effects are especially aggravated when the unmodified graphite anode operates at low temperatures (below $25^{\circ} \mathrm{C}$ ) [112] and/or a high charging rate. Thus, these factors are attributed to the lithium plates on the SEI surface of the anode. If these moss-like metallic deposits and dendrites continue to grow between the polymer separator and the anode, a short circuit is created, which then can lead to thermal runway and battery failure $[11,98]$.

3.2. Anode Mechanical Failure. Fracture and decrepitation of the electrodes are critical challenges existing in lithium-ion batteries as a result of lithium diffusion during the charging and discharging operations. When lithium ions intercalate and deintercalate into/from the graphite electrode, a large volume change on the order of a few to several hundred percent can occur. Diffusion-induced stresses (DISs) can therefore cause the nucleation and growth of cracks, leading to mechanical degradation of the active electrode materials [113]. Cuenot et al. [114] have clarified the influence of the nanowire radius on the mechanical properties, including the apparent stiffness and tensile modulus. Hence, for nanoscale electrode structures, surface energies and surface stresses can be expected to have a significant impact on the mechanical properties of the electrode materials. Additionally, cycling the lithium-ion batteries at high C-rate and high state of charge (SOC) induce mechanical strain on the graphite lattice of the anode electrode due to the steep gradient of lithium ions [98]. Nevertheless, graphite exfoliation and particle cracking rising from solution cointercalation, electrolyte reduction, and gas evolution inside the graphite will definitely cause a rapid decay of the electrode $[96,97]$. In particular, the gas evolution, which accelerates cell aging, is considered to exert a tremendous influence on the changes of the active materials [53].

3.3. Anode Electrochemical Aging. The resistance rise of the electrode, which has a significant correlation with power fading of the whole cell, has been measured by many researchers [56-59, 110-118]. The resistance rise is considered to result from the thickening of the SEI along with the continual chemical changes of the SEI [60-64]. Additionally, the thickness and constituents of the SEI membranes deposited on aged electrodes were further researched by inductively coupled plasma (ICP) and EDX measurements [6].

The effects of different temperatures on the anode electrochemical characteristics are prominent: The kinetics of the lithium intercalation/deintercalation into/from the anode materials are significantly accelerated at elevated temperatures, and the structure and morphology of the SEI are expected to change with a rise of temperature [55-64]. The thermal runaway may lead to fire or explosion of the cell in some extreme cases. Thus, the SEM and X-ray diffraction (XRD) have been adopted by different groups to explore the electrode or cell thermal characteristics at elevated temperatures [119-121].

Furthermore, it is generally accepted that some basic mechanisms exist that account for the general aging phenomena in the lithium batteries, although each battery may possess different electrochemical behaviours. The strong reactivity of the electrolyte and lithium ions and the stability of the SEI are the main contributors to the stability of the overall cell. Thus, a modified graphite electrode with properly chosen active materials and electrolyte results in an anode that is stable during both storage and cycling $[53,98]$.

3.4. Conclusion on Anode Aging. The aging mechanisms of the anode, in addition to those intrinsic to the anode, may predominantly be ascribed to changes of the electrode and electrolyte at the interface between them. Summarizing in brief, we can conclude that the main mechanisms of the anode aging occur for the following reasons:

(i) Changes at the anode/electrolyte interface: the SEI membrane is fabricated during the first electrochemical charge and then further evolves with precipitation on the anode during cycling and storage. Moreover, interactions of the anode with the cathode and metallic lithium plating must be considered as significant factors in the anode aging.

(ii) Mechanical failure such as graphite exfoliation and particle cracking leads to isolation of active materials, which subsequently aggravates electrode aging.

(iii) Anode electrochemical aging characteristics: some side reactions at the electrode/solution interface or the SEI and electrolytes, together with the contact loss within the composite anode materials, consequently result in a resistance rise of electrode. 


\section{Conclusions}

Battery aging generally manifests in the form of a power/ capacity decrease and impedance/inner resistance rise during storage and cycle. This review presented the aging mechanisms of electrode materials in lithium-ion batteries, elaborating on the causes, effects, and their results, taking place during a battery's life as well as the methods adopted to mitigate the aging phenomena in lithium-ion batteries. Structural disordering and mechanical effects are the predominant aspects of aging of cathode materials used in lithium-ion batteries upon cycling. However, the cathode, by applying state-of-the-art doped materials, such as $\mathrm{Al}, \mathrm{Mg}$, and Cl-doped lithium-nickel-cobalt-mixed-oxides, exhibits good cycling stability. Additionally, phase transitions are dependent on the high state of charge and upper cutoff voltage. Moreover, the lifespan of cathode materials, for example, lithium-manganese spinel, extended by operating within reasonable electrochemical potential windows and temperature ranges. Further, the capacity fading can be attributed to the loss of cyclable lithium and active materials due to the formation and development of an irreversible SEI membrane at the anode. Additionally, the SEI membrane is unstable when exposed to elevated temperatures, which is another cause of continuous lithium consumption and the consequent capacity fading as the surface membrane is increasingly rebuilt. Elevated temperatures and high storage potentials initiate the decomposition of the electrolyte's components. This effect is probably not caused by electrolyte decomposition alone and may be caused by a porous surface layer that is permeable for the electrolytes but acts as a hindering layer.

\section{Conflict of Interests}

The authors declare that there is no conflict of interests regarding the publication of this paper.

\section{Acknowledgments}

This work was supported by the National Sci-Tech Support Plan (no. 2014BAG02B02) and International S\&T Cooperation Program of China (ISTCP) (no. 2015DFG81930). The authors would like to thank Dr. Rui Xiong at Beijing Institute of Technology for many helpful discussions. They are also grateful to all of the anonymous reviewers for providing useful comments and suggestions that resulted in the improved quality of this paper.

\section{References}

[1] F. Sun, R. Xiong, and H. He, "A systematic state-of-charge estimation framework for multi-cell battery pack in electric vehicles using bias correction technique," Applied Energy, 2014.

[2] C. D. Rahn and C.-Y. Wang, Battery Systems Engineering, John Wiley \& Sons, 2013.

[3] H. Kim and J. Cho, "Hard templating synthesis of mesoporous and nanowire $\mathrm{SnO}_{2}$ lithium battery anode materials," Journal of Materials Chemistry, vol. 18, no. 7, pp. 771-775, 2008.
[4] M. F. Hassan, Z. Guo, Z. Chen, and H. Liu, " $\alpha-\mathrm{Fe}_{2} \mathrm{O}_{3}$ as an anode material with capacity rise and high rate capability for lithiumion batteries," Materials Research Bulletin, vol. 46, no. 6, pp. 858864, 2011.

[5] S. Vyazovkin, "On the phenomenon of variable activation energy for condensed phase reactions," New Journal of Chemistry, vol. 24, no. 11, pp. 913-917, 2000.

[6] T. Waldmann, M. Wilka, M. Kasper, M. Fleischhammer, and M. Wohlfahrt-Mehrens, "Temperature dependent ageing mechanisms in Lithium-ion batteries-a Post-Mortem study," Journal of Power Sources, vol. 262, pp. 129-135, 2014.

[7] W. Waag, S. Käbitz, and D. U. Sauer, "Experimental investigation of the lithium-ion battery impedance characteristic at various conditions and aging states and its influence on the application," Applied Energy, vol. 102, no. 2, pp. 885-897, 2013.

[8] A. Barré, B. Deguilhem, S. Grolleau, M. Gérard, F. Suard, and D. Riu, "A review on lithium-ion battery ageing mechanisms and estimations for automotive applications," Journal of Power Sources, vol. 241, pp. 680-689, 2013.

[9] U. Tröltzsch, O. Kanoun, and H.-R. Tränkler, "Characterizing aging effects of lithium ion batteries by impedance spectroscopy," Electrochimica Acta, vol. 51, no. 8-9, pp. 1664-1672, 2006.

[10] G.-B. Cho, T.-H. Kwon, T.-H. Nam et al., "Structural and electrochemical properties of lithium nickel oxide thin films," Journal of Chemistry, vol. 2014, Article ID 824083, 5 pages, 2014.

[11] J. Vetter, P. Novák, M. R. Wagner et al., "Ageing mechanisms in lithium-ion batteries," Journal of Power Sources, vol. 147, no. 1-2, pp. 269-281, 2005.

[12] K. C. Kam and M. M. Doeff, "Electrode materials for lithium ion batteries," Material Matters, vol. 7, no. 4, 2012.

[13] B.-L. He, B. Dong, and H.-L. Li, "Preparation and electrochemical properties of Ag-modified $\mathrm{TiO}_{2}$ nanotube anode material for lithium-ion battery," Electrochemistry Communications, vol. 9, no. 3, pp. 425-430, 2007.

[14] M. Kunduraci, J. F. Al-Sharab, and G. G. Amatucci, "Highpower nanostructured $\mathrm{LiMn}_{2-x} \mathrm{Ni}_{x} \mathrm{O}_{4}$ high-voltage lithium-ion battery electrode materials: electrochemical impact of electronic conductivity and morphology," Chemistry of Materials, vol. 18, no. 15, pp. 3585-3592, 2006.

[15] Y. Idota, T. Kubota, A. Matsufuji, Y. Maekawa, and T. Miyasaka, "Tin-based amorphous oxide: a high-capacity lithium-ionstorage material," Science, vol. 276, no. 5317, pp. 1395-1397, 1997.

[16] J.-M. Tarascon and M. Armand, "Issues and challenges facing rechargeable lithium batteries," Nature, vol. 414, no. 6861, pp. 7359-7367, 2001.

[17] X. W. Lou, D. Deng, J. Y. Lee, J. Feng, and L. A. Archer, "Self-supported formation of needlelike $\mathrm{Co}_{3} \mathrm{O}_{4}$ nanotubes and their application as lithium-ion battery electrodes," Advanced Materials, vol. 20, no. 2, pp. 258-262, 2008.

[18] K. A. Smith, C. D. Rahn, and C.-Y. Wang, "Control oriented 1D electrochemical model of lithium ion battery," Energy Conversion and Management, vol. 48, no. 9, pp. 2565-2578, 2007.

[19] Y.-D. Li, S.-X. Zhao, C.-W. Nan, and B.-H. Li, "Electrochemical performance of $\mathrm{SiO}_{2}$-coated $\mathrm{LiFePO}_{4}$ cathode materials for lithium ion battery," Journal of Alloys and Compounds, vol. 509, no. 3, pp. 957-960, 2011.

[20] H. Ikuta, K. Takanaka, and M. Wakihara, "The effect of chromium substitution on the phase transition of lithium manganese spinel oxides," Thermochimica Acta, vol. 414, no. 2, pp. 227-232, 2004. 
[21] J. Lv, Y. Wang, L. Zhu, and Y. Ma, "Predicted novel high-pressure phases of lithium," Physical Review Letters, vol. 106, no. 1, Article ID 015503, 2011.

[22] M. Wohlfahrt-Mehrens, A. Butz, R. Oesten, G. Arnold, R. P. Hemmer, and R. A. Huggins, "The influence of doping on the operation of lithium manganese oxide spinel," Journal of Power Sources, vol. 68, no. 2, pp. 582-585, 1997.

[23] E. Rezlescu, L. Sachelarie, P. D. Popa, and N. Rezlescu, "Effect of substitution of divalent ions on the electrical and magnetic properties of Ni-Zn-Me ferrites," IEEE Transactions on Magnetics, vol. 36, no. 6, pp. 3962-3967, 2000.

[24] H.-M. Zhang, N. Yamazoe, and Y. Teraoka, "Effects of B site partial substitutions of perovskite-type $\mathrm{La}_{0.6} \mathrm{Sr}_{0.4} \mathrm{CoO}_{3}$ on oxygen desorption," Journal of Materials Science Letters, vol. 8, no. 9, pp. 995-996, 1989.

[25] P. He, H. Yu, D. Li, and H. Zhou, "Layered lithium transition metal oxide cathodes towards high energy lithium-ion batteries," Journal of Materials Chemistry, vol. 22, no. 9, pp. 36803695, 2012.

[26] S.-H. Park, H.-S. Shin, S.-T. Myung, C. S. Yoon, K. Amine, and Y.-K. Sun, "Synthesis of nanostructured $\mathrm{Li}\left[\mathrm{Ni}_{1 / 3} \mathrm{Co}_{1 / 3} \mathrm{Mn}_{1 / 3}\right] \mathrm{O}_{2}$ via a modified carbonate process," Chemistry of Materials, vol. 17, no. 1, pp. 6-8, 2005.

[27] D. M. Yu, S. T. Zhang, D. W. Liu et al., "Effect of manganese doping on Li-ion intercalation properties of $\mathrm{V}_{2} \mathrm{O}_{5}$ films," Journal of Materials Chemistry, vol. 20, no. 48, pp. 10841-10846, 2010.

[28] D.-W. Han, W.-H. Ryu, W.-K. Kim, J.-Y. Eom, and H.-S. Kwon, "Effects of $\mathrm{Li}$ and $\mathrm{Cl}$ codoping on the electrochemical performance and structural stability of $\mathrm{LiMn}_{2} \mathrm{O}_{4}$ cathode materials for hybrid electric vehicle applications," The Journal of Physical Chemistry C, vol. 117, no. 10, pp. 4913-4919, 2013.

[29] M. A. Macias, O. Mentré, C. Pirovano, P. Roussel, S. Colis, and G. H. Gauthier, "Influence of the synthesis route on the formation of $12 \mathrm{R} / 10 \mathrm{H}$-polytypes and their magnetic properties within the $\mathrm{Ba}(\mathrm{Ce}, \mathrm{Mn}) \mathrm{O}_{3}$ family," New Journal of Chemistry, vol. 39, pp. 829-835, 2015.

[30] V. Cicek and A. Apblett, "Synthesis and characterization of salts and esters of hydroxy acids as corrosion inhibitors for mild steel and aluminum alloys," Journal of Chemistry and Chemical Engineering, vol. 5, pp. 1160-1170, 2011.

[31] C. Julien, S. Ziolkiewicz, M. Lemal, and M. Massot, "Synthesis, structure and electrochemistry of $\mathrm{LiMn}_{2-y} \mathrm{Al}_{y} \mathrm{O}_{4}$ prepared by a wet-chemistry method," Journal of Materials Chemistry, vol. 11, no. 7, pp. 1837-1842, 2001.

[32] M. Kaneko, S. Matsuno, T. Miki et al., "Local structural studies of LiCryMn $\mathrm{Mn}_{2-y} \mathrm{O}_{4}$ cathode materials for Li-Ion batteries," Journal of Physical Chemistry B, vol. 107, no. 8, pp. 1727-1733, 2003.

[33] J. R. Dahn, E. W. Fuller, M. Obrovac, and U. von Sacken, "Thermal stability of $\mathrm{Li}_{x} \mathrm{CoO}_{2}, \mathrm{Li}_{x} \mathrm{NiO}_{2}$ and $\lambda-\mathrm{MnO}_{2}$ and consequences for the safety of Li-ion cells," Solid State Ionics, vol. 69, no. 3-4, pp. 265-270, 1994.

[34] S. Albrecht, J. Kümpers, M. Kruft et al., "Electrochemical and thermal behavior of aluminum- and magnesium-doped spherical lithium nickel cobalt mixed oxides $\mathrm{Li}_{1-x}\left(\mathrm{Ni}_{1-y-z} \mathrm{CoyM}_{z}\right) \mathrm{O}_{2}$ $(\mathrm{M}=\mathrm{Al}, \mathrm{Mg})$," Journal of Power Sources, vol. 119-121, pp. 178-183, 2003.

[35] N. Yabuuchi and T. Ohzuku, "Novel lithium insertion material of $\mathrm{LiCo}_{1 / 3} \mathrm{Ni}_{1 / 3} \mathrm{Mn}_{1 / 3} \mathrm{O}_{2}$ for advanced lithium-ion batteries," Journal of Power Sources, vol. 119-121, pp. 171-174, 2003.

[36] J. Choi and A. Manthiram, "Role of chemical and structural stabilities on the electrochemical properties of layered
$\mathrm{LiNi}_{1 / 3} \mathrm{Mn}_{1 / 3} \mathrm{Co}_{1 / 3} \mathrm{O}_{2}$ cathodes," Journal of the Electrochemical Society, vol. 152, no. 9, pp. A1714-A1718, 2005.

[37] A. Manthiram, A. V. Murugan, A. Sarkar, and T. Muraliganth, "Nanostructured electrode materials for electrochemical energy storage and conversion," Energy \& Environmental Science, vol. 1, no. 6, pp. 621-638, 2008.

[38] G. T.-K. Fey, Y. Y. Lin, and T. Prem Kumar, "Enhanced cyclability and thermal stability of $\mathrm{LiCoO}_{2}$ coated with cobalt oxides," Surface and Coatings Technology, vol. 191, no. 1, pp. 6875, 2005.

[39] X. Zhang, F. Cheng, J. Yang, and J. Chen, " $\mathrm{LiNi}_{0.5} \mathrm{Mn}_{1.5} \mathrm{O}_{4}$ porous nanorods as high-rate and long-life cathodes for $\mathrm{Li}$-ion batteries," Nano Letters, vol. 13, no. 6, pp. 2822-2825, 2013.

[40] S. Banerjee, S. Roy, J. W. Chen, and D. Chakravorty, "Magnetic properties of oxide-coated iron nanoparticles synthesized by electrodeposition," Journal of Magnetism and Magnetic Materials, vol. 219, no. 1, pp. 45-52, 2000.

[41] M. R. Palacín, G. G. Amatucci, M. Anne et al., "Electrochemical and structural study of the $3.3 \mathrm{~V}$ reduction step in defective $\mathrm{Li}_{x} \mathrm{Mn}_{2} \mathrm{O}_{4}$ and $\mathrm{LiMn}_{2} \mathrm{O}_{(4-y)} \mathrm{F}_{y}$ compounds," Journal of Power Sources, vol. 81-82, pp. 627-631, 1999.

[42] B. L. Ellis, K. T. Lee, and L. F. Nazar, "Positive electrode materials for Li-Ion and Li-batteries," Chemistry of Materials, vol. 22, no. 3, pp. 691-714, 2010.

[43] C. Vogler, B. Löffler, W. Weirather, M. Wohlfahrt-Mehrens, and J. Garche, "Doped lithium nickel cobalt mixed oxides for the positive electrode in Lithium Ion Batteries," Ionics, vol. 8, no. 1-2, pp. 92-99, 2002.

[44] M. Broussely, P. Blanchard, P. Biensan, J. P. Planchat, K. Nechev, and R. J. Staniewicz, "Properties of large Li ion cells using a nickel based mixed oxide," Journal of Power Sources, vol. 119-121, pp. 859-864, 2003.

[45] C.-J. Kim, I.-S. Ahn, K.-K. Cho, S.-G. Lee, and J.-K. Chung, "Characteristics of $\mathrm{LiNiO}_{2}$ thin films synthesized by Li diffusion on the surface oxidized epitaxial layer of Ni-alloy," Journal of Alloys and Compounds, vol. 449, no. 1-2, pp. 335-338, 2008.

[46] N. N. Bramnik, K. Nikolowski, G. Baehtz, K. G. Bramnik, and $\mathrm{H}$. Ehrenberg, "Phase transitions occurring upon lithium insertion-extraction of $\mathrm{LiCoPO}_{4}$," Chemistry of Materials, vol. 19, no. 4, pp. 908-915, 2007.

[47] D. R. Macfarlane, J. Huang, and M. Forsyth, "Lithium-doped plastic crystal electrolytes exhibiting fast ion conduction for secondary batteries," Nature, vol. 402, no. 6763, pp. 792-794, 1999.

[48] W.-S. Yoon, S. Iannopollo, C. P. Grey et al., "Local structure and cation ordering in $\mathrm{O}_{3}$ lithium nickel manganese oxides with stoichiometry $\mathrm{Li}\left[\mathrm{Ni}_{x} \mathrm{Mn}_{(2-x) / 3} \mathrm{Li}_{(1-2 x) / 3}\right] \mathrm{O}_{2}$ NMR studies and first principles calculations," Electrochemical and Solid-State Letters, vol. 7, no. 7, pp. A167-A171, 2004.

[49] A. Hirano, R. Kanno, Y. Kawamoto, K. Oikawab, T. Kamiyama, and F. Izumi, "Neutron diffraction study of the layered $\mathrm{Li}_{0.5-x} \mathrm{Ni}_{1+x} \mathrm{O}_{2}$," Solid State Ionics, vol. 86-88, no. 2, pp. 791-796, 1996.

[50] B. Xu, C. R. Fell, M. Chi, and Y. S. Meng, "Identifying surface structural changes in layered $\mathrm{Li}$-excess nickel manganese oxides in high voltage lithium ion batteries: a joint experimental and theoretical study," Energy and Environmental Science, vol. 4, no. 6, pp. 2223-2233, 2011.

[51] M. S. Whittingham, "Lithium batteries and cathode materials," Chemical Reviews, vol. 104, no. 10, pp. 4271-4301, 2004. 
[52] M. Tang, W. C. Carter, and Y.-M. Chiang, "Electrochemically driven phase transitions in insertion electrodes for lithium-ion batteries: examples in lithium metal phosphate olivines," Annual Review of Materials Research, vol. 40, pp. 501-529, 2010.

[53] M. A. L. Nobre and S. Lanfredi, "Phase transition in sodium lithium niobate polycrystal: an overview based on impedance spectroscopy," Journal of Physics and Chemistry of Solids, vol. 62, no. 11, pp. 1999-2006, 2001.

[54] Y. Chen, Q. Jiao, L. Wang et al., "Synthesis and characterization of $\mathrm{Li}_{1.05} \mathrm{Co}_{1 / 3} \mathrm{Ni}_{1 / 3} \mathrm{Mn}_{1 / 3} \mathrm{O}_{1.95} \mathrm{X}_{0.05}(\mathrm{X}=\mathrm{Cl}, \mathrm{Br})$ cathode materials for lithium-ion battery," Comptes Rendus Chimie, vol. 16, no. 9, pp. 845-849, 2013.

[55] S. Komaba, W. Murata, T. Ishikawa et al., "Electrochemical $\mathrm{Na}$ insertion and solid electrolyte interphase for hard-carbon electrodes and application to Na-ion batteries," Advanced Functional Materials, vol. 21, no. 20, pp. 3859-3867, 2011.

[56] E. Hosono, T. Kudo, I. Honma, H. Matsuda, and H. Zhou, "Synthesis of single crystalline spinel $\mathrm{LiMn}_{2} \mathrm{O}_{4}$ nanowires for a lithium ion battery with high power density," Nano Letters, vol. 9, no. 3, pp. 1045-1051, 2009.

[57] L. M. L. Fransson, J. T. Vaughey, R. Benedek, K. Edström, J. O. Thomas, and M. M. Thackeray, "Phase transitions in lithiated $\mathrm{Cu}_{2} \mathrm{Sb}$ anodes for lithium batteries: an in situ X-ray diffraction study," Electrochemistry Communications, vol. 3, no. 7, pp. 317323, 2001.

[58] J. Morales, C. Pérez-Vicente, and J. L. Tirado, "Cation distribution and chemical deintercalation of $\mathrm{Li}_{1-x} \mathrm{Ni}_{1+x} \mathrm{O}_{2}$," Materials Research Bulletin, vol. 25, no. 5, pp. 623-630, 1990.

[59] S. P. Lin, K. Z. Fung, Y. M. Hon, and M. H. Hon, "Crystallization mechanism of $\mathrm{LiNiO}_{2}$ synthesized by Pechini method," Journal of Crystal Growth, vol. 226, no. 1, pp. 148-157, 2001.

[60] K. Xu, "Nonaqueous liquid electrolytes for lithium-based rechargeable batteries," Chemical Reviews, vol. 104, no. 10, pp. 4303-4417, 2004.

[61] K. Kumai, K. Takei, Y. Kobayashi, H. Mlyashiro, and R. Ishikawa, "Mechanism of electrolyte decomposition in practical lithium-ion cell after long charge and discharge cycles," Denki Kagaku, vol. 66, no. 3, pp. 314-320, 1998.

[62] S. A. Freunberger, Y. Chen, N. E. Drewett, L. J. Hardwick, F. Bardé, and P. G. Bruce, "The lithium-oxygen battery with etherbased electrolytes," Angewandte Chemie International Edition, vol. 50, no. 37, pp. 8609-8613, 2011.

[63] D. P. Abraham, R. D. Twesten, M. Balasubramanian, I. Petrov, J. McBreen, and $\mathrm{K}$. Amine, "Surface changes on $\mathrm{LiNi}_{0.8} \mathrm{Co}_{0.2} \mathrm{O}_{2}$ particles during testing of high-power lithium-ion cells," Electrochemistry Communications, vol. 4, no. 8, pp. 620-625, 2002.

[64] S. Venkatraman, Y. Shin, and A. Manthiram, "Phase relationships and structural and chemical stabilities of charged $\mathrm{Li}_{1-x} \mathrm{CoO}_{2-\delta}$ and $\mathrm{Li}_{1-x} \mathrm{Ni}_{0.85} \mathrm{Co}_{0.15} \mathrm{O}_{2-\delta}$ cathodes," Electrochemical and Solid-State Letters, vol. 6, no. 1, pp. A9-A12, 2003.

[65] Z. Chen and J. R. Dahn, "Studies of $\mathrm{LiCoO}_{2}$ coated with metal oxides," Electrochemical and Solid-State Letters, vol. 6, no. 11, pp. A221-A224, 2003.

[66] L. Gao, S. Liu, and R. A. Dougal, "Dynamic lithium-ion battery model for system simulation," IEEE Transactions on Components and Packaging Technologies, vol. 25, no. 3, pp. 495505, 2002.

[67] A. Magasinski, P. Dixon, B. Hertzberg, A. Kvit, J. Ayala, and G. Yushin, "High-performance lithium-ion anodes using a hierarchical bottom-up approach," Nature Materials, vol. 9, no. 4, pp. 353-358, 2010.
[68] S. Akao, M. Yamada, and T. Kodera, "Powder characterization and electrochemical properties of $\mathrm{LiNi}_{0.5} \mathrm{Mn}_{1.5} \mathrm{O}_{4}$ cathode materials produced by large spray pyrolysis using flame combustion," Advances in Materials Science and Engineering, vol. 2011, Article ID 768143, 6 pages, 2011.

[69] J.-Y. Luo and Y.-Y. Xia, "Aqueous lithium-ion battery $\mathrm{LiTi}_{2}\left(\mathrm{PO}_{4}\right)_{3} / \mathrm{LiMn}_{2} \mathrm{O}_{4}$ with high power and energy densities as well as superior cycling stability," Advanced Functional Materials, vol. 17, no. 18, pp. 3877-3884, 2007.

[70] K. A. Smith, C. D. Rahn, and C.-Y. Wang, "Model-based electrochemical estimation and constraint management for pulse operation of lithium ion batteries," IEEE Transactions on Control Systems Technology, vol. 18, no. 3, pp. 654-663, 2010.

[71] Z.-S. Wu, W. Ren, L. Wen et al., "Graphene anchored with $\mathrm{Co}_{3} \mathrm{O}_{4}$ nanoparticles as anode of lithium ion batteries with enhanced reversible capacity and cyclic performance," ACS Nano, vol. 4, no. 6, pp. 3187-3194, 2010.

[72] I. Hadjipaschalis, A. Poullikkas, and V. Efthimiou, "Overview of current and future energy storage technologies for electric power applications," Renewable and Sustainable Energy Reviews, vol. 13, no. 6-7, pp. 1513-1522, 2009.

[73] D. Aurbach, B. Markovsky, A. Rodkin et al., "On the capacity fading of $\mathrm{LiCoO}_{2}$ intercalation electrodes: the effect of cycling, storage, temperature, and surface film forming additives," Electrochimica Acta, vol. 47, no. 27, pp. 4291-4306, 2002.

[74] H.-W. Lee, P. Muralidharan, R. Ruffo, C. M. Mari, Y. Cui, and D. K. Kim, "Ultrathin spinel $\mathrm{LiMn}_{2} \mathrm{O}_{4}$ nanowires as high power cathode materials for Li-ion batteries," Nano Letters, vol. 10, no. 10, pp. 3852-3856, 2010.

[75] C. H. Chen, J. Liu, and K. Amine, "Symmetric cell approach towards simplified study of cathode and anode behavior in lithium ion batteries," Electrochemistry Communications, vol. 3, no. 1, pp. 44-47, 2001.

[76] C. K. Chan, H. Peng, G. Liu et al., "High-performance lithium battery anodes using silicon nanowires," Nature Nanotechnology, vol. 3, no. 1, pp. 31-35, 2008.

[77] Y. Moritomo, M. Takachi, Y. Kurihara, and T. Matsudal, "Synchrotron-radiation X-ray investigation of $\mathrm{Li}^{+} / \mathrm{Na}^{+}$intercalation into prussian blue analogues," Advances in Materials Science and Engineering, vol. 2013, Article ID 967285, 17 pages, 2013.

[78] R. Xiong, F. Sun, H. He, and T. D. Nguyen, "A data-driven adaptive state of charge and power capability joint estimator of lithium-ion polymer battery used in electric vehicles," Energy, vol. 63, pp. 295-308, 2013.

[79] R. Kostecki and F. McLarnon, "Degradation of $\mathrm{LiNi}_{0.8} \mathrm{Co}_{0.2} \mathrm{O}_{2}$ Cathode surfaces in high-power lithium-ion batteries," Electrochemical and Solid-State Letters, vol. 5, no. 7, pp. A164-A166, 2002.

[80] R. Xiong, F. Sun, Z. Chen, and H. He, "A data-driven multi-scale extended Kalman filtering based parameter and state estimation approach of lithium-ion olymer battery in electric vehicles," Applied Energy, vol. 113, no. 1, pp. 463-476, 2014.

[81] N. Sato, K. Hirao, E. Hayashi, and G. Katagiri, "Characterization of electrode materials during degradation process of Li-ion batteries," Nippon Kagaku Kaishi, vol. 2002, no. 2, pp. 189-194, 2002.

[82] K. S. Ng, C. S. Moo, Y. P. Chen, and Y. C. Hsieh, "Enhanced coulomb counting method for estimating state-of-charge and state-of-health of lithium-ion batteries," Applied Energy, vol. 86, no. 9, pp. 1506-1511, 2009. 
[83] L. Li, J. Ge, F. Wu, R. Chen, S. Chen, and B. Wu, "Recovery of cobalt and lithium from spent lithium ion batteries using organic citric acid as leachant," Journal of Hazardous Materials, vol. 176, no. 1-3, pp. 288-293, 2010.

[84] S. M. Shin, N. H. Kim, J. S. Sohn, D. H. Yang, and Y. H. Kim, "Development of a metal recovery process from Li-ion battery wastes," Hydrometallurgy, vol. 79, no. 3-4, pp. 172-181, 2005.

[85] H. Li and H. Zhou, "Enhancing the performances of Liion batteries by carbon-coating: present and future," Chemical Communications, vol. 48, no. 9, pp. 1201-1217, 2012.

[86] Z. Y. Chen, X. Q. Liu, L. Z. Gao, and Z. L. Yu, "Electrochemical capacity fading in high temperature of spinel $\mathrm{LiMn}_{2} \mathrm{O}_{4}$ and its improvement," Chinese Journal of Inorganic Chemistry, vol. 17, no. 3, pp. 325-330, 2001.

[87] U. Mehmood, S.-U. Rahman, K. Harrabi, I. A. Hussein, and B. V. S. Reddy, "Recent advances in dye sensitized solar cells," Advances in Materials Science and Engineering, vol. 2014, Article ID 974782, 12 pages, 2014.

[88] J. Cho, G. B. Kim, and H. S. Lim, "Improvement of structural stability of $\mathrm{LiMn}_{2} \mathrm{O}_{4}$ cathode material on $55^{\circ} \mathrm{C}$ cycling by sol-gel coating of $\mathrm{LiCoO}_{2}$," Electrochemical and Solid-State Letters, vol. 2, no. 12, pp. 607-609, 1999.

[89] J. Nan, D. Han, M. Yang, M. Cui, and X. Hou, "Recovery of metal values from a mixture of spent lithium-ion batteries and nickelmetal hydride batteries," Hydrometallurgy, vol. 84, no. 1-2, pp. 75-80, 2006.

[90] S. Komaba, N. Kumagai, T. Sasaki, and Y. Miki, "Manganese dissolution from lithium doped Li-Mn-O spinel cathode materials into electrolyte solution," Electrochemistry, vol. 69, no. 10, pp. 784-787, 2001.

[91] H. Oka, S. Kasahara, T. Okada et al., "Structural analysis of lithium-excess lithium manganate cathode materials by ${ }^{7} \mathrm{Li}$ magic-angle spinning nuclear magnetic resonance spectroscopy," Solid State Ionics, vol. 144, no. 1-2, pp. 19-29, 2001.

[92] L. Sun and K. Qiu, "Vacuum pyrolysis and hydrometallurgical process for the recovery of valuable metals from spent lithiumion batteries," Journal of Hazardous Materials, vol. 194, pp. 378384, 2011.

[93] H. Liu, J. Li, Z. Zhang, Z. Gong, and Y. Yang, "The effects of sintering temperature and time on the structure and electrochemical performance of $\mathrm{LiNi}_{0.8} \mathrm{Co}_{0.2} \mathrm{O}_{2}$ cathode materials derived from sol-gel method," Journal of Solid State Electrochemistry, vol. 7, no. 8, pp. 456-462, 2003.

[94] G. G. Amatucci, J. M. Tarascon, and L. C. Klein, "Cobalt dissolution in $\mathrm{LiCoO}_{2}$-based non-aqueous rechargeable batteries," Solid State Ionics, vol. 83, no. 1-2, pp. 167-173, 1996.

[95] B. Saha, S. Poll, K. Goebel, and J. Christophersen, "An integrated approach to battery health monitoring using bayesian regression and state estimation," in Proceedings of the IEEE Autotestcon, pp. 646-653, September 2007.

[96] M. Winter, J. O. Besenhard, M. E. Spahr, and P. Novák, "Insertion electrode materials for rechargeable lithium batteries," Advanced Materials, vol. 10, no. 10, pp. 725-763, 1998.

[97] R. Xiong, F. Sun, X. Gong, and C. Gao, "A data-driven based adaptive state of charge estimator of lithium-ion polymer battery used in electric vehicles," Applied Energy, vol. 113, no. 1, pp. 1421-1433, 2014.

[98] V. Agubra and J. Fergus, "Lithium ion battery anode aging mechanisms," Materials, vol. 6, no. 4, pp. 1310-1325, 2013.

[99] D. Aurbach, E. Zinigrad, Y. Cohen, and H. Teller, "A short review of failure mechanisms of lithium metal and lithiated graphite anodes in liquid electrolyte solutions," Solid State Ionics, vol. 148, no. 3-4, pp. 405-416, 2002.

[100] P. Lu, C. Li, E. W. Schneider, and S. J. Harris, "Chemistry, impedance, and morphology evolution in solid electrolyte interphase films during formation in lithium ion batteries," The Journal of Physical Chemistry C, vol. 118, no. 2, pp. 896-903, 2014.

[101] R. Fu, S.-Y. Choe, V. Agubra, and J. Fergus, "Development of a physics-based degradation model for lithium ion polymer batteries considering side reactions," Journal of Power Sources, vol. 278, pp. 506-521, 2015.

[102] P. Handel, G. Fauler, K. Kapper et al., "Thermal aging of electrolytes used in lithium-ion batteries-an investigation of the impact of protic impurities and different housing materials," Journal of Power Sources, vol. 267, pp. 255-259, 2014.

[103] P. Röder, B. Stiaszny, J. C. Ziegler, N. Baba, P. Lagaly, and H.-D. Wiemhöfer, "The impact of calendar aging on the thermal stability of a $\mathrm{LiMn}_{2} \mathrm{O}_{4}-\mathrm{Li}\left(\mathrm{Ni}_{1 / 3} \mathrm{Mn}_{1 / 3} \mathrm{Co}_{1 / 3}\right) \mathrm{O}_{2}$ /graphite lithiumion cell," Journal of Power Sources, vol. 268, pp. 315-325, 2014.

[104] T. E. Furtak, "Anomalously intense Raman scattering at the solid-electrolyte interface," Solid State Communications, vol. 28, no. 11, pp. 903-906, 1978.

[105] O. Borodin and D. Bedrov, "Interfacial structure and dynamics of the lithium alkyl dicarbonate SEI components in contact with the lithium battery electrolyte," The Journal of Physical Chemistry C, vol. 118, no. 32, pp. 18362-18371, 2014.

[106] W. Haiss and J. K. Sass, "Adsorbate-induced surface stress at the solid/electrolyte interface measured with an STM," Journal of Electroanalytical Chemistry, vol. 386, no. 1-2, pp. 267-270, 1995.

[107] B. Prélot, C. Poinsignon, F. Thomas, E. Schouller, and F. Villiéras, "Structural-chemical disorder of manganese dioxides 1. Influence on surface properties at the solid-electrolyte interface," Journal of Colloid and Interface Science, vol. 257, no. 1, pp. 77-84, 2003.

[108] S. Zhang, M. S. Ding, K. Xu, J. Allen, and T. R. Jow, “Understanding solid electrolyte interface film formation on graphite electrodes," Electrochemical and Solid-State Letters, vol. 4, no. 12, pp. A206-A208, 2001.

[109] M. Lu, H. Cheng, and Y. Yang, "A comparison of solid electrolyte interphase (SEI) on the artificial graphite anode of the aged and cycled commercial lithium ion cells," Electrochimica Acta, vol. 53, no. 9, pp. 3539-3546, 2008.

[110] D. Goers, M. E. Spahr, A. Leone, W. Märkle, and P. Novák, “The influence of the local current density on the electrochemical exfoliation of graphite in lithium-ion battery negative electrodes," Electrochimica Acta, vol. 56, no. 11, pp. 3799-3808, 2011.

[111] F.-M. Wang, M.-H. Yu, Y.-J. Hsiao et al., "Aging effects to solid electrolyte interface (SEI) membrane formation and the performance analysis of lithium ion batteries," International Journal of Electrochemical Science, vol. 6, no. 4, pp. 1014-1026, 2011.

[112] D. Zhang, B. S. Haran, A. Durairajan, R. E. White, Y. Podrazhansky, and B. N. Popov, "Studies on capacity fade of lithium-ion batteries," Journal of Power Sources, vol. 91, no. 2, pp. 122-129, 2000.

[113] R. Deshpande, Y.-T. Cheng, and M. W. Verbrugge, "Modeling diffusion-induced stress in nanowire electrode structures," Journal of Power Sources, vol. 195, no. 15, pp. 5081-5088, 2010.

[114] S. Cuenot, C. Frétigny, S. Demoustier-Champagne, and B. Nysten, "Surface tension effect on the mechanical properties of nanomaterials measured by atomic force microscopy," Physical Review B, vol. 69, no. 16, Article ID 165410, 2004. 
[115] A. Matasso, D. Wetz Jr., and F. Liu, "The effects of internal pressure evolution on the aging of commercial Li-Ion cells," ECS Transactions, vol. 58, no. 46, pp. 37-44, 2014.

[116] T. Jiang, S. Zhang, X. Qiu, W. Zhu, and L. Chen, "Preparation and characterization of silicon-based three-dimensional cellular anode for lithium ion battery," Electrochemistry Communications, vol. 9, no. 5, pp. 930-934, 2007.

[117] S. S. Zhang, "A review on electrolyte additives for lithium-ion batteries," Journal of Power Sources, vol. 162, no. 2, pp. 1379-1394, 2006.

[118] Q. Y. Chen and K. X. Wei, "Estimation of electric vehicle battery ohmic resistance using dual extend kalman filter," Applied Mechanics and Materials, vol. 391, pp. 246-249, 2013.

[119] Y. Wang, J. Jiang, and J. R. Dahn, "The reactivity of delithiated $\mathrm{Li}\left(\mathrm{Ni}_{1 / 3} \mathrm{Co}_{1 / 3} \mathrm{Mn}_{1 / 3}\right) \mathrm{O}_{2}$, $\mathrm{Li}\left(\mathrm{Ni}_{0.8} \mathrm{Co}_{0.15} \mathrm{Al}_{0.05}\right) \mathrm{O}_{2}$ or $\mathrm{LiCoO}_{2}$ with non-aqueous electrolyte," Electrochemistry Communications, vol. 9, no. 10, pp. 2534-2540, 2007.

[120] W.-M. Zhang, X.-L. Wu, J.-S. Hu, Y.-G. Guo, and L.-J. Wan, "Carbon coated $\mathrm{Fe}_{3} \mathrm{O}_{4}$ nanospindles as a superior anode material for lithium-ion batteries," Advanced Functional Materials, vol. 18, no. 24, pp. 3941-3946, 2008.

[121] G. Wang, X. Shen, J. Yao, and J. Park, "Graphene nanosheets for enhanced lithium storage in lithium ion batteries," Carbon, vol. 47, no. 8, pp. 2049-2053, 2009. 

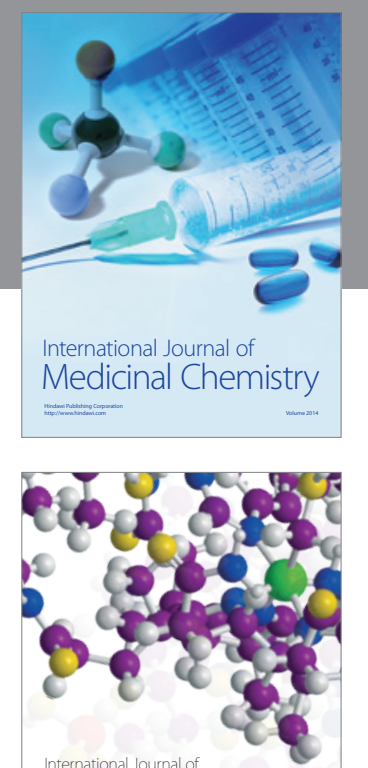

\section{Carbohydrate} Chemistry

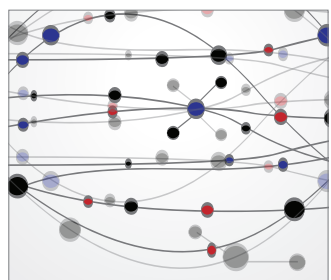

The Scientific World Journal
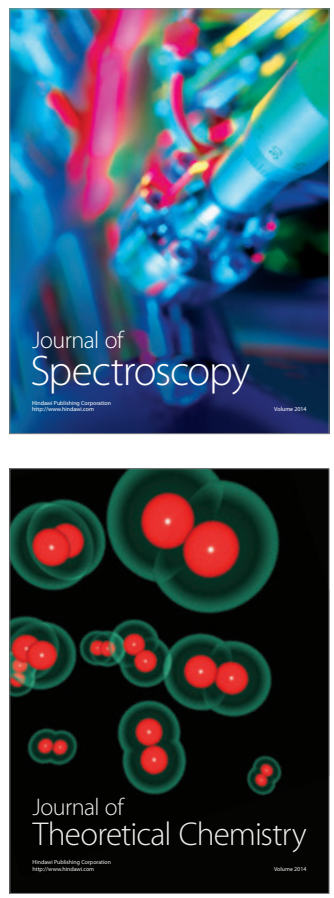
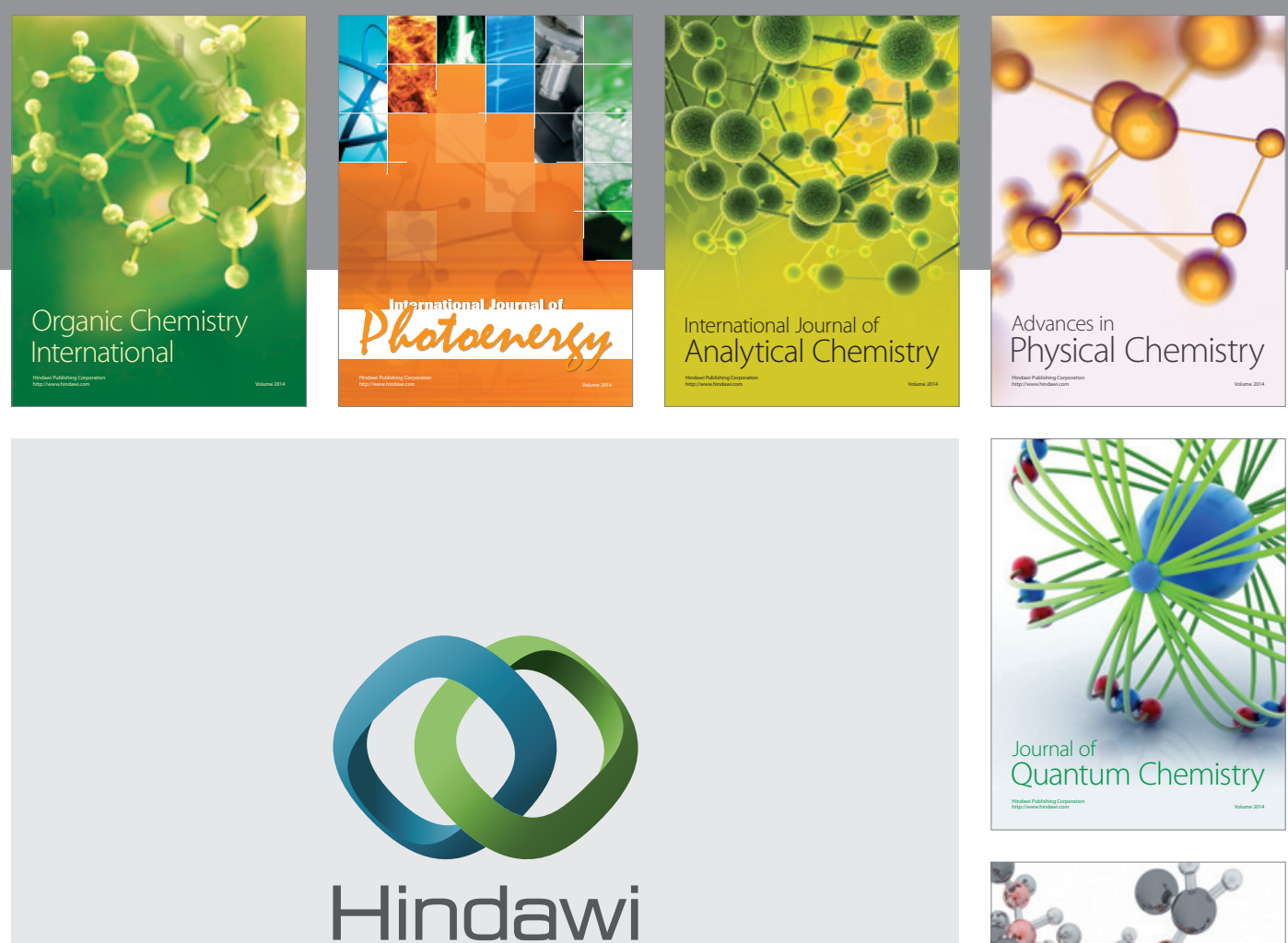

Submit your manuscripts at

http://www.hindawi.com

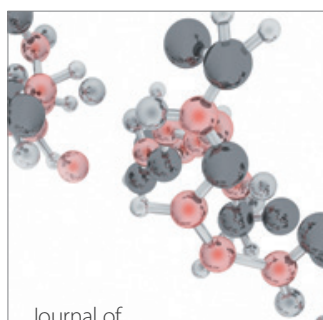

Analytical Methods

in Chemistry

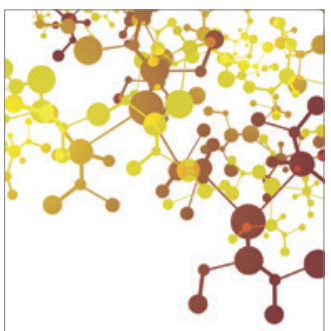

Journal of

Applied Chemistry

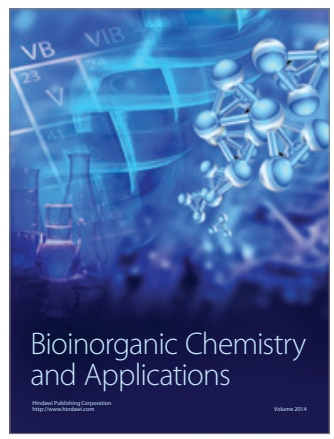

Inorganic Chemistry
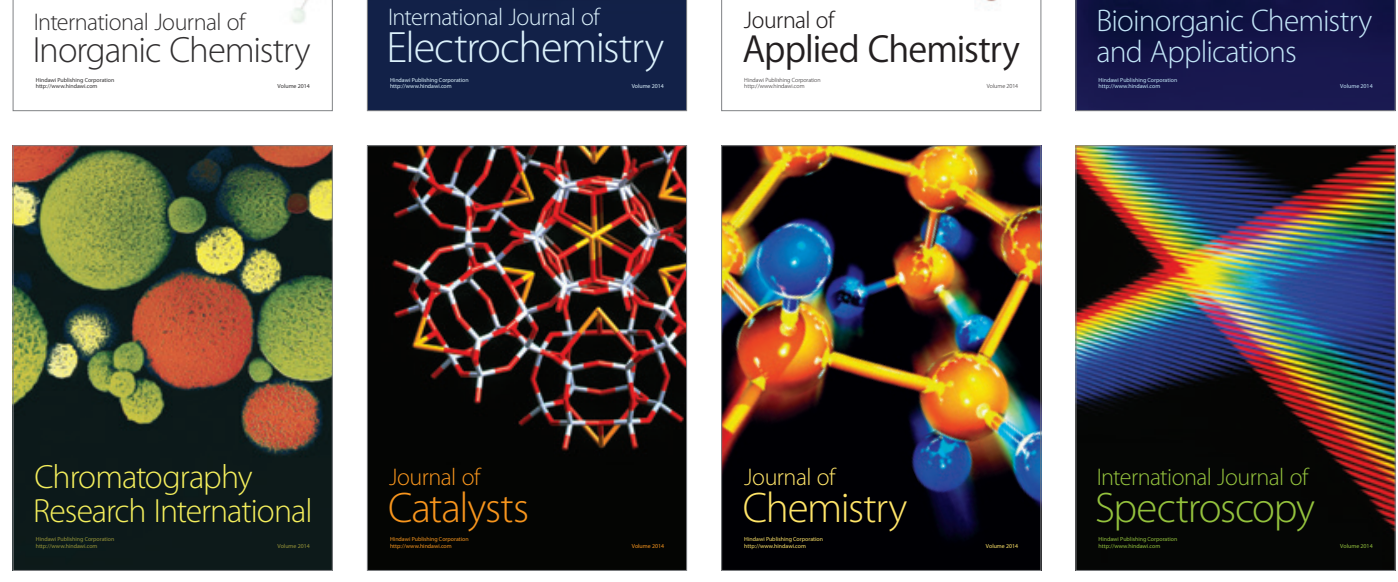